\title{
Role of Biochar Amendment on Soil Carbon Mineralization and Microbial Biomass
}

\author{
Yimin Wang1*, Ming Li² \\ ${ }^{1}$ College of Environment, Hohai University, Nanjing, China \\ ${ }^{2}$ MCC Huatian Nanjing Engineering \& Technology Corporation, Nanjing, China \\ Email: *wangym@hhu.edu.cn
}

How to cite this paper: Wang, Y. M., \& Li, M. (2018). Role of Biochar Amendment on Soil Carbon Mineralization and Microbial Biomass. Journal of Geoscience and Environment Protection, 6, 173-180. https://doi.org/10.4236/gep.2018.611013

Received: November 22, 2018

Accepted: November 27, 2018

Published: November 30, 2018

\begin{abstract}
To understand the influence of biochar properties (pyrolysis temperature and types) on soil physicochemical properties, we investigated the changes of soil organic carbon mineralization, nutrient contents and microbial biomass after $135 \mathrm{~d}$ incubation. Results showed that both corn straw (CB) and rice straw (RB) derived biochars increase the mineralization of organic carbon and nitrogen in the soil, and these biochars pyrolysised at $500^{\circ} \mathrm{C}$ (CB500, RB500) significantly enhanced the mineralization of soil organic nitrogen. In comparison with control treatment, the application of biochar significantly increased the contents of soil organic carbon, available $\mathrm{P}$ and $\mathrm{K}$ in soil. Moreover, the activity of soil microbe was enhanced with biochar amendment. Among all treatments, RB500 significantly increased the content of soil microbial biomass carbon $\left(379 \pm 9 \mathrm{mg} \cdot \mathrm{kg}^{-1}\right)$ in soil. Our results suggested that the application of biochars to soil improve soil quality, while the biochar type and pyrolysis temperature should be taken into consideration before its application in agro-ecosystem.
\end{abstract}

\section{Keywords}

Biochar, Soil, Soil Carbon Mineralization, Microbial Biomass

\section{Introduction}

With $\sim 620$ million tons of plant straw generated annually, China has an abundant biomass resource for various utilizations including its direct field return for increasing of soil organic carbon (SOC) accumulation (Zeng et al., 2007). One of the emerging strategies is to convert straw into biochar, a recalcitrant carbon-rich product obtained after pyrolysis under limited oxygen environment. (Lehmann et al., 2006) Biochar has advantages over fresh straw in enhancing the 
capacity of long-term carbon (C) sequestration in soil. As one of the most important $\mathrm{C}$ pools on the global scale, the incorporation of biochar to soil serves as a long-term C sink (Lehmann, et al., 2006). The stabilization and transformation of $\mathrm{C}$ in biochar amended soil with respect to the inherent biochar $\mathrm{C}$ and the native SOC has been extensively investigated (Singh et al., 2014). However, there is a critical knowledge gap in how the influences of biochar pyrolysis temperatures and types on soil carbon mineralization.

Biochar derived from straw is not only an organic substance rich in carbon, but also contains a variety of nutrient elements such as nitrogen, oxygen, sulfur and inorganic carbonate components (Sanchez-Monedero et al., 2017). Studies have suggested that biochar amendment to soil can influence soil microbial biomass, activity and community structure (Farrell et al., 2013). Such microbial responses might occur because of the potential utilization of biochar as an energy source by microorganisms (Domene et al., 2014), as a habitat for microorganisms from grazers and as components to improve soil properties such as water holding capacity and nutrient availability (Wu et al., 2013). Although straw return to soil could also stimulate the growth and activity of microorganisms, increased emissions of greenhouse gas did always happen (Kuzyakov et al., 2014). In contrast, biochar amendment could decrease such emissions, and has a sustainable effect on soil microbial activity and diversity (Kolb, et al., 2009). However, studies of biochar amendment on soil microbial properties were not consistent, likely due to variations in soil types (Gomez et al., 2014), biochar types and pyrolysis temperatures (Jones et al., 2012). Moreover, Jones et al. (Jones et al., 2012) also concluded that various effects of biochar on soil behaviour from laboratory studies were closely associated with its properties and incubation time. Therefore, we should pay attention to the role of biochar characteristics on the activities of soil microorganism.

\section{Material and Methods}

\subsection{Soil Characterization}

The bulk soil, located at $0-20 \mathrm{~cm}$, was collected from Yingtan, Jiangxi province of China. This region is characterized as subtropical marine climate with mean annual precipitation of $1100-1785 \mathrm{~mm}$, mean annual temperature of $13^{\circ} \mathrm{C}$ $17^{\circ} \mathrm{C}$. Collected soil was aired dried and sieved through $2 \mathrm{~mm}$ for future experiments. Soil $\mathrm{pH}$ was measured from a soil-water suspension $(1: 2.5 \mathrm{w} / \mathrm{v})$ with a $\mathrm{pH}$ meter (Metler Toledo). Soil organic carbon (SOC) was determined by TOC analyzer (Multi N/C 3000). Soil total N was measured by Kjeldahl method, soil available $\mathrm{N}$ by the alkali hydrolysable method, soil available $\mathrm{P}$ by the Olsen method, and soil available $\mathrm{K}$ by the NH4OAC extraction. Soil total $\mathrm{P}$ and $\mathrm{K}$ were digested by $\mathrm{HF}-\mathrm{HClO}_{4}$ and determined by the molybdenum-blue colorimetry and flame photometry, respectively. Measurement of soil CEC was accorded to the ammonium acetate compulsory displacement method (Yuan et al., 2011) (Table 1). 
Table 1. The properties of tested soil.

\begin{tabular}{ccccccc}
\hline $\mathrm{pH}$ & $\begin{array}{c}\text { SOC } \\
\mathrm{g} \cdot \mathrm{kg}^{-1}\end{array}$ & $\begin{array}{c}\text { Total N } \\
\mathrm{g} \cdot \mathrm{kg}^{-1}\end{array}$ & $\begin{array}{c}\text { Available N } \\
\mathrm{mg} \cdot \mathrm{kg}^{-1}\end{array}$ & $\begin{array}{c}\text { Available P } \\
\mathrm{mg} \cdot \mathrm{kg}^{-1}\end{array}$ & $\begin{array}{c}\text { Available K } \\
\mathrm{mg} \cdot \mathrm{kg}^{-1}\end{array}$ & $\begin{array}{c}\text { CEC } \\
\mathrm{cmol} \cdot \mathrm{kg}^{-1}\end{array}$ \\
\hline 5.57 & 20.87 & 2.17 & 261.33 & 54.63 & 130.00 & 8.37 \\
\hline
\end{tabular}

\subsection{Biochar Preparation}

Two biochar materials were pyrolyzed from rice straw (RB), and corn straw (CB) under a limited-oxygen condition at different temperatures using a patented slow-pyrolysis process (China Patent No. ZL200920232191.9). Briefly, Straw materials were oven-dried for $12 \mathrm{~h}$ at $80^{\circ} \mathrm{C}$ before moved to a reactor, which was heated by $5^{\circ} \mathrm{C} \min ^{-1}$ to $300^{\circ} \mathrm{C}, 400^{\circ} \mathrm{C}$, and $400^{\circ} \mathrm{C}$ respectively. And then the reactor was maintained at designed temperature for $4 \mathrm{~h}$ till no further smoke exhaust. Biochar was then ground and sieved through a $0.25-\mathrm{mm}$ mesh before further application. Detailed pyrolysis process was described in previous studies (Li et al., 2016). Then we obtained six biochar materials and denoted as RB300, RB400, RB500, and CB300, CB400, CB500. The characteristics of these obtained biochar samples were reported in our previous published papers (Ming, et al., 2016).

\subsection{Soil Incubation and Microbial Analysis}

$100 \mathrm{~g}$ air dried soil was weighed into a $500-\mathrm{mL}$ plastic bottle, the obtained biochar samples were uniformly mixed with soil at a level of $1 \%(\mathrm{w} / \mathrm{w})$ respectively. The biochar amended soil was adjusted to $60 \%$ of the saturated water-holding capacity every three days, and then incubated at $25^{\circ} \mathrm{C}$ in a temperature-controlled incubator for $135 \mathrm{~d}$. The bottles were covered with sterile membranes that permitted gaseous exchange and minimized moisture loss. Each treatment has three replications.

Soil samples were collected three times, on 45, 90 and $135 \mathrm{~d}$, after which changes in soil microbial biomass carbon (MBC) contents were determined. Changes in soil properties such as the soil $\mathrm{pH}$ values, SOC, available $\mathrm{N}$, available $\mathrm{P}$ and available $\mathrm{K}$ contents were measured at the end of incubation period (135 d).

\subsection{Soil Carbon Mineralization in Soil}

The mineralization of soil organic carbon was determined by indoor incubation and lye absorption method. Weigh $100 \mathrm{~g}$ of air-dried soil sample into $500 \mathrm{ml}$ plastic bottle, add appropriate amount of deionized water to adjust to $60 \%$ of saturated water content, mix well, and pre-incubation for 1 week in a constant temperature incubator at $25^{\circ} \mathrm{C} \pm 1^{\circ} \mathrm{C}$. Seven treatments were designed. The biochar material was added at a level of $1 \%(\mathrm{w} / \mathrm{w})$ to ensure that the material is thoroughly mixed with the soil, and each treatment was set to 3 replicates. The incubation bottles were sealed with a sterile membrane to ensure good aeration conditions in the bottle and the water was periodically added to maintain a con- 
stant water content. The $\mathrm{NaOH}$-containing absorption bottles were taken out on the 1st, $2 \mathrm{nd}, 4 \mathrm{th}, 7 \mathrm{th}, 14 \mathrm{th}, 21 \mathrm{th}, 28 \mathrm{th}, 42 \mathrm{th}, 56 \mathrm{th}$ and 72 th days of the incubation period, and the excess $\mathrm{BaCl}_{2}$ solution and the indicator were added respectively, and the hydrochloric acid was titrated to the end point with the calibration hydrochloric acid to calculate the amount of $\mathrm{CO}_{2}$ released during the incubation period. The amount of total $\mathrm{CO}_{2}$ evolution and net nitrogen mineralization were determined according to the alkali absorption method. Net nitrogen mineralization was calculated as $\left(\mathrm{NO}_{3}^{-}+\mathrm{NH}_{4}^{+}\right)_{72 \mathrm{~d}}-\left(\mathrm{NO}_{3}^{-}+\mathrm{NH}_{4}^{+}\right)_{0 \mathrm{~d}}$. Soil $(5.0 \mathrm{~g})$ was extracted with $50 \mathrm{~mL} 2 \mathrm{M} \mathrm{KCl}$, shaken for $1 \mathrm{~h}$, filtered and the amounts of $\mathrm{NH}_{4}^{+}$ and $\mathrm{NO}_{3}^{-}$in solution were quantified using an automatic $\mathrm{NH}_{4}^{+}$and $\mathrm{NO}_{3}^{-}$ analyzer (Bran + Lubbe AA3, Germany).

\subsection{Data Analysis}

Student-Newman-Keuls (S-N-K) of one-way ANOVA was applied to assess the significant differences $(\mathrm{p}<0.05)$ among groups using SPSS 21.0. Data are presented as mean \pm SD $(n=3)$. Charts and graphs were drawn by Sigmaplot 10.0 .

\section{Results and Discussion}

\subsection{Style and Spacing Change of Soil Organic Carbon Mineralization}

During the incubation period, the mineralization rate of soil organic carbon gradually decrease, especially in the early stage of incubation, which is mainly related to the gradual decrease of available organic carbon in the soil (Figure 1). The results of different treatments showed that the addition of two biochar materials did not significantly affect the mineralization rate of organic carbon in the soil. The effects of the addition of biochar from different pyrolysis temperatures on the mineralization rate of soil organic carbon were not significant. However,

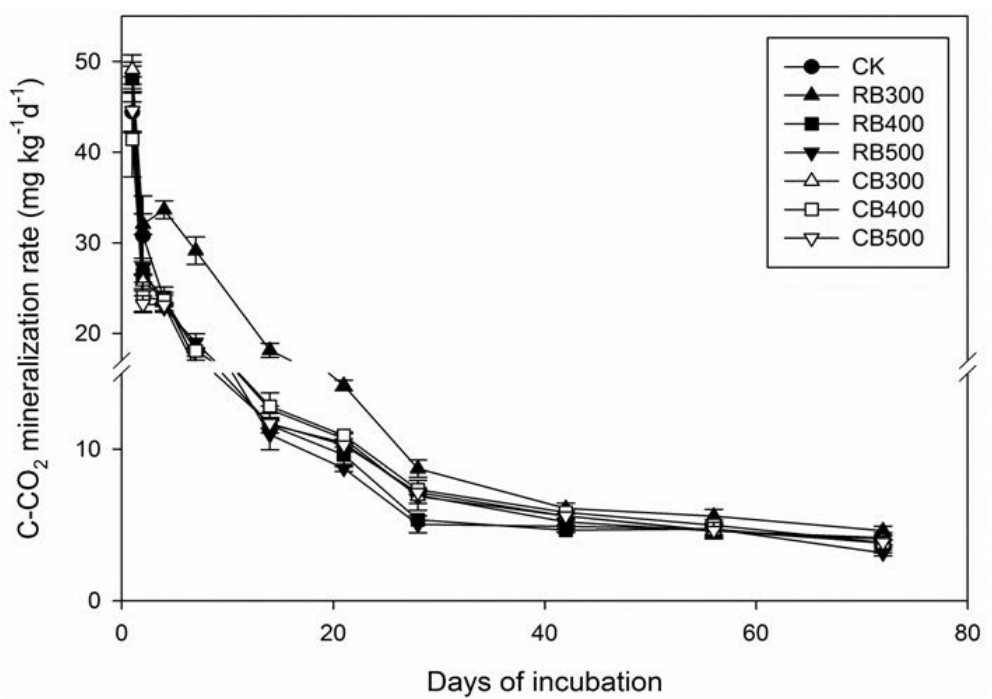

Figure 1. Responses of $\mathrm{C}$ mineralization rate to different biochar addition during the incubation period. 
the addition of RB300, induced a higher mineralization rate of soil organic carbon than other treatments, which may be related to the relatively high available organic carbon content in biochar material that pyrolysised at $300^{\circ} \mathrm{C}$. Previous studies have shown that biochar materials prepared at lower temperatures usually richer in available organic carbon content than biochar materials prepared at higher temperatures.

The results of cumulative mineralization of organic carbon showed that the accumulation of organic carbon in RB300 treatment was the highest, which was $790 \pm 15 \mathrm{mg} \mathrm{C}-\mathrm{CO}_{2} \mathrm{~kg}^{-1}$ soil, which was significantly higher than that of the control treatment, while the other additions of biochar did not significantly change the cumulative mineralization of organic carbon. All the addition of biochars at different pyrolysis temperatures increased the mineralization of nitrogen in the soil to varying degrees, especially with the additions of RB500 and CB500, which significantly increased the nitrogen mineralization with $136 \mathrm{mg}$ $\left(\mathrm{NO}_{3}^{-}+\mathrm{NH}_{4}^{+}\right) \mathrm{kg}^{-1}$ soil and $97 \mathrm{mg}\left(\mathrm{NO}_{3}^{-}+\mathrm{NH}_{4}^{+}\right) \mathrm{kg}^{-1}$ soil respectively. This indicates that the addition of biochar material can promote the conversion of soil organic nitrogen to inorganic nitrogen to some extent, which is consent with the previous studies (Table 2).

\subsection{Change of Soil Chemistry Properties}

After 135 days of incubation, the $\mathrm{pH}$ value of biochar treatments increased by an average of 0.16 units compared with the control, but the difference between the additions of biochars that pyrolysised at the same temperature was not significant (Table 3, $p<0.05$ ). Compared to CK treatment, contents of organic carbon, available phosphorus and available potassium in biochar mediated soils increased by $26.1 \%, 20.6 \%$ and $282 \%$, respectively. There was no significant difference in soil organic carbon content between the two straw biochar treatments; the addition of RB materials significantly increased the soil available potassium content, which was higher than the average treatment of corn straw biochar, while the incorporation of corn biochar induced $9.0 \%$ incensement on the average

Table 2. The cumulative mineralization of organic carbon and nitrogen.

\begin{tabular}{|c|c|c|c|c|}
\hline \multirow{2}{*}{ Treatment } & $\begin{array}{c}\text { Cumulative } \\
\text { mineralization } \mathrm{C}\end{array}$ & $\begin{array}{c}\text { Net } \\
\text { mineralization }\end{array}$ & $\begin{array}{c}\text { Cumulative } \\
\text { mineralization } \mathrm{N}\end{array}$ & $\begin{array}{c}\text { Net } \\
\text { mineralization }\end{array}$ \\
\hline & \multicolumn{2}{|c|}{$\mathrm{mg} \mathrm{C}-\mathrm{CO}_{2} \mathrm{~kg}^{-1}$ soil } & $\mathrm{mg}\left(\mathrm{NO}_{3}^{-}+\right.$ & $\mathrm{NH}_{4}^{+}$) $\mathrm{kg}^{-1}$ soil \\
\hline CK & $603 \pm 18 c$ & & $283 \pm 21 a$ & \\
\hline RB300 & $790 \pm 15 d$ & 188 & $313 \pm 47 \mathrm{ab}$ & 30 \\
\hline RB400 & $567 \pm 17 \mathrm{ab}$ & -36 & $318 \pm 32 \mathrm{ab}$ & 34 \\
\hline RB500 & $549 \pm 9 a$ & -53 & $419 \pm 19 b$ & 136 \\
\hline CB300 & $616 \pm 12 c$ & 14 & $288 \pm 38 \mathrm{ab}$ & 5 \\
\hline CB400 & $613 \pm 9 c$ & 11 & $325 \pm 53 \mathrm{ab}$ & 42 \\
\hline CB500 & $585 \pm 14 b c$ & -17 & $380 \pm 60 b$ & 97 \\
\hline
\end{tabular}


Table 3. Chemical properties of soils under different biochar amendments after 135 days of incubation.

\begin{tabular}{cccccc}
\hline Treatment & $\mathrm{pH}$ & $\begin{array}{c}\text { SOC } \\
\mathrm{g} \mathrm{kg}\end{array}$ & $\begin{array}{c}\text { Available N } \\
\mathrm{mg} \cdot \mathrm{kg}^{-1}\end{array}$ & $\begin{array}{c}\text { Available P } \\
\mathrm{mg} \cdot \mathrm{kg}^{-1}\end{array}$ & $\begin{array}{c}\text { Available K } \\
\mathrm{mg} \cdot \mathrm{kg}^{-1}\end{array}$ \\
\hline CK & $4.33 \pm 0.03 \mathrm{a}$ & $20.8 \pm 0.7 \mathrm{a}$ & $216.8 \pm 7.3 \mathrm{bc}$ & $82.1 \pm 3.1 \mathrm{a}$ & $123.1 \pm 2.4 \mathrm{a}$ \\
RB300 & $4.48 \pm 0.04 \mathrm{bc}$ & $26.3 \pm 0.6 \mathrm{~b}$ & $207.6 \pm 9.2 \mathrm{abc}$ & $94.4 \pm 0.7 \mathrm{~b}$ & $528.1 \pm 27.7 \mathrm{~d}$ \\
RB400 & $4.53 \pm 0.04 \mathrm{~cd}$ & $26.3 \pm 0.3 \mathrm{~b}$ & $187.4 \pm 7.3 \mathrm{a}$ & $93.9 \pm 2.7 \mathrm{~b}$ & $568.8 \pm 21.7 \mathrm{e}$ \\
RB500 & $4.58 \pm 0.03 \mathrm{~d}$ & $25.0 \pm 3.1 \mathrm{~b}$ & $190.8 \pm 6.0 \mathrm{a}$ & $93.9 \pm 2.6 \mathrm{~b}$ & $623.8 \pm 10.5 \mathrm{f}$ \\
CB300 & $4.45 \pm 0.02 \mathrm{~b}$ & $25.9 \pm 0.7 \mathrm{~b}$ & $227.9 \pm 19.9 \mathrm{c}$ & $100.5 \pm 1.4 \mathrm{c}$ & $362.5 \pm 10.2 \mathrm{bc}$ \\
CB400 & $4.46 \pm 0.02 \mathrm{bc}$ & $26.3 \pm 0.8 \mathrm{~b}$ & $218.7 \pm 3.7 \mathrm{bc}$ & $102.7 \pm 1.3 \mathrm{c}$ & $390.6 \pm 12.0 \mathrm{c}$ \\
CB500 & $4.43 \pm 0.04 \mathrm{~b}$ & $27.0 \pm 1.2 \mathrm{~b}$ & $198.5 \pm 6.0 \mathrm{ab}$ & $104.3 \pm 2.1 \mathrm{c}$ & $350.0 \pm 10.2 \mathrm{~b}$ \\
\hline
\end{tabular}

in soil available phosphorus than rice straw biochar $(p<0.05)$. The difference of soil organic carbon, available phosphorus and available potassium between the different pyrolysis temperatures of the same material did not significant $(p<$ 0.05). The addition of low temperature pyrolysis straw biochar $\left(300^{\circ} \mathrm{C}\right)$ did not significant affect the soil alkali nitrogen content; while the application of RB400, RB500 and CB500 treatment significantly decrease the alkali nitrogen content by $10.4 \%$ and $8.1 \%$, respectively $(p<0.05)$. Previous studies have also shown that the addition of biochar promotes the mineralization of soil organic nitrogen, thereby reducing the reduction of available organic nitrogen in the soil.

\subsection{Change of Soil Microbial Biomass}

The concentrations of microbial biomass carbon (MBC) in all treatments decreased during the incubation period, and the overall content of MBC was $45 \mathrm{~d}>$ $90 \mathrm{~d}>135 \mathrm{~d}$, indicating that the activity of microorganisms in the soil gradually reduced. Possible reasons due to the available nutrients in the soil. Results of different incubation time showed that the addition of biochar materials with different pyrolysis temperatures can promote the activity of microorganisms in soil to some extent, and the content of MBC in each treatment is higher than that of CK treatment. After 135 days of incubation, the soil microbial biomass carbon content was $185 \pm 26 \mathrm{mg} \cdot \mathrm{kg}^{-1}$ in CK (Figure 2). The addition of straw biochar that pyrolysised at a low temperature $\left(300^{\circ} \mathrm{C}\right)$ did not significantly affect the $\mathrm{MBC}$ content, while the addition of straw biochars that prepared from $400^{\circ} \mathrm{C}$ and $500^{\circ} \mathrm{C}$ pyrolysis temperature significantly increased the $\mathrm{MBC}$ content by $50.1 \%$ and $84.3 \%(p<0.05)$, respectively. With the addition of biochar pyrolysised at the same temperature, the effect of RB500 induced more incensement in $\mathrm{MBC}$ content than CB500, which is nearly $379 \pm 9 \mathrm{mg} \cdot \mathrm{kg}^{-1}$ in the soil.

\section{Conclusion}

1) Biochar could increase the mineralization of organic carbon and nitrogen in the soil, especially the biochar prepared under low temperature conditions. 


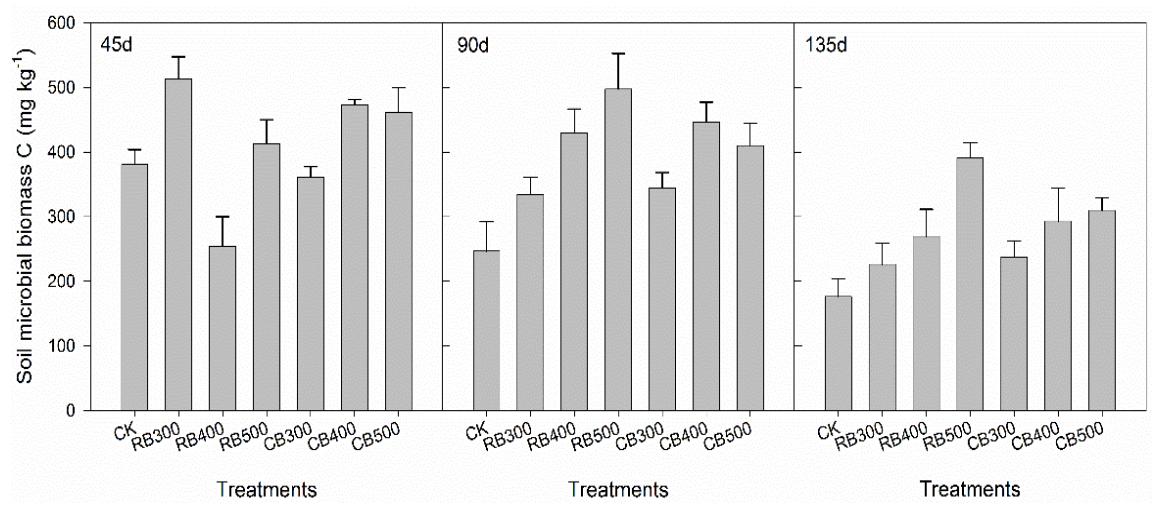

Figure 2. Concentrations of microbial biomass carbon for soils with and without biochar amendment after 45, 90 and 135 days of incubation.

2) Biochar addition promoted the activity of microbial populations in the soil. Rice straw biochar pyrolysised at $500^{\circ} \mathrm{C}$ can significantly increase the content of soil microbial biomass carbon in soil.

\section{Acknowledgements}

This work was supported by the Foundation Research Project of Jiangsu Province (BK20160155; BK20160859).

\section{Conflicts of Interest}

The authors declare no conflicts of interest regarding the publication of this paper.

\section{References}

Domene, X., Mattana, S., Hanley, K., Enders, A., \& Lehmann, J. (2014). Medium-Term Effects of Corn Biochar Addition on Soil Biota Activities and Functions in a Temperate Soil Cropped to Corn. Soil BiolBiochem., 72, 152-162. https://doi.org/10.1016/j.soilbio.2014.01.035

Farrell, M., Kuhn, T. K., Macdonald, L. M., Maddern, T. M., Murphy, D. V., Hall, P. A., Singh, B. P., Baumann, K., Krull, E. S., \& Baldock, J. A. (2013). Microbial Utilisation of Biochar-Derived Carbon. Science of The Total Environment, 465, 288-297. https://doi.org/10.1016/j.scitotenv.2013.03.090

Gomez, J. D., Denef, K., Stewart, C. E., Zheng, J., \& Cotrufo, M. F. (2014). Biochar Addition Rate Influences Soil Microbial Abundance and Activity in Temperate Soils. European Journal of Soil Science, 65, 28-39. https://doi.org/10.1111/ejss.12097

Jones, D. L., Rousk, J., Edwards-Jones, G., DeLuca, T. H., \& Murphy, D. V. (2012). Biochar-Mediated Changes in Soil Quality and Plant Growth in a Three Year Field Trial. Soil Biology and Biochemistry, 45, 113-124. https://doi.org/10.1016/j.soilbio.2011.10.012

Kolb, S. E., Fermanich, K. J., \& Dornbush, M. E. (2009). Effect of Charcoal Quantity on Microbial Biomass and Activity in Temperate Soils. Soil Science Society of America Journal, 73, 1173-1181. https://doi.org/10.2136/sssaj2008.0232

Kuzyakov, Y., Bogomolova, I., \& Glaser, B. (2014). Biochar Stability in Soil: Decomposition during Eight Years and Transformation as Assessed by Compound-Specific ${ }^{14} \mathrm{C}$ 
Analysis. Soil Biology and Biochemistry, 70, 229-236.

https://doi.org/10.1016/j.soilbio.2013.12.021

Lehmann, J., Gaunt, J., \& Rondon, M. (2006). Bio-Char Sequestration in Terrestrial Ecosystems-A Review. Mitigation and Adaptation Strategies for Global Change, 11, 395-419. https://doi.org/10.1007/s11027-005-9006-5

Ming, L. I., Ming, L. I. U., Li, Z. P., Jiang, C. Y., \& Meng, W. U. (2016). Soil N Transformation and Microbial Community Structure as Affected by Adding Biochar to a Paddy Soil of Subtropical China. Journal of Integrative Agriculture, 15, 209-219. https://doi.org/10.1016/S2095-3119(15)61136-4

Sanchez-Monedero, M. A., Cayuela, M. L., Roig, A., Jindo, K., Mondini, C., \& Bolan, N. (2017). Role of Biochar as an Additive in Organic Waste Composting. Bioresource Technology, 247, 1155-1164. https://doi.org/10.1016/j.biortech.2017.09.193

Singh, N., Abiven, S., Maestrini, B., Bird, J. A., Torn, M. S., Schmidt.M. W.I. (2014). Transformation and Stabilization of Pyrogenic Organic Matter in a Temperate Forest Field Experiment. Global Change Biology, 20, 1629-1642.

https://doi.org/10.1111/gcb.12459

Wu, F. P., Jia, Z. K., Wang, S. G., Chang, S. X., \& Startsev, A. (2013). Contrasting Effects of Wheat Straw and Its Biochar on Greenhouse Gas Emissions and Enzyme Activities in a Chernozemic Soil. Biology and Fertility of Soils, 49, 555-565.

https://doi.org/10.1007/s00374-012-0745-7

Yuan, J. H., Xu, R. K., Qian, W., \& Wang, R. H. (2011). Comparison of the Ameliorating effects on an Acidic Ultisol between Four Crop Straws and Their Biochars. Journal of Soils and Sediments, 11, 741-750. https://doi.org/10.1007/s11368-011-0365-0

Zeng, X. Y., Ma, Y. T., \& Ma, L. R. (2007). Utilization of Straw in Biomass Energy in China. Renewable and Sustainable Energy Reviews, 11, 976-987.

https://doi.org/10.1016/j.rser.2005.10.003 